\title{
THE CHROMOSOME CONSTANCY OF THE NORMAL MAMMALIAN UTERUS
}

\author{
LEO SACHS \\ Department of Experimental Biology, Weizmann Institute of Science, \\ Rehovoth, Israel
}

Received I I.V.53

\section{INTRODUCTION}

Mammalian chromosomes have mainly been examined either in cells of the testis in the male or in cells of the ovary in the female. These tissues, which contain the sex cells, have to be used for studies on meiosis so that they have also been used for studies on mitosis. In addition the testes contain the best normal cells for accurate chromosome counts so that most investigations have been restricted to this one tissue.

Other mammalian tissues have rarely been examined and there are only a few earlier studies on the chromosomes of normal somatic tissues. These have included reports on the occurrence of many somatic cells with less than the diploid number of chromosomes and they have always been a subject of controversy (Karplus, 1930 ; Kemp, I930 ; Andres and Jiv, 1936). A more recent report on somatic tissues includes a study on the uterus of the human female. Here it is reported (Timonen, 1950 ; Timonen and Therman, 1950 ; Therman and Timonen, 195I) that the endometrium of the human uterus normally contains cells with numbers ranging from 4 to IO4 chromosomes. The frequency distribution of these different chromosome numbers is reported as showing two main peaks. The highest peak is supposed to lie in cells with 20 to 25 chromosomes, with a much lower peak in cells with 45 to 50 chromosomes.

Some subdiploid variation can be found in certain mammalian tumours, and the comparison of normal and malignant tissues is an essential basis for an understanding of cancer. The existence of extensive subdiploid variation in normal somatic tissues would thus be of great importance in interpreting the origin of subdiploid cancer cells. A knowledge of the chromosomes of somatic tissues is also of importance for an understanding of the processes of development and differentiation.

The present study was therefore undertaken in order to see if extensive subdiploid variation is really a characteristic of normal somatic mammalian tissues. Many tissues of adult mammals have very few or no mitotic figures so that the chromosomes can no longer be studied after differentiation. But the endometrium is especially favourable in this respect as the uterine responses during the œstrus 
cycle are correlated with periods of miotic activity. The most extensive subdiploid variation has been reported in the human endometrium and the present study therefore includes an examination of this human tissue. As the cestrus cycle in primates including man differs in some respects from that in other mammals, I have also examined the normal endometrium of the two rodents Rattus norvegicus and Microtus agrestis. This study on three different mammals provides concrete data on the chromosomes of normal somatic tissues.

\section{MATERIAL AND TECHNIQUES}

The human material used in the present study comes from women in England and in Israel. The endometrium was removed by biopsy and in all cases there were no signs of cancerous growth. The material from England was obtained through Dr J. O'Sullivan, Bethnal Green Hospital, London, and the material in Israel was obtained through Dr A. Mielnicky, Kupat Cholim, Jaffa. Immediately after removal from the body small pieces of endometrium were fixed in $\mathrm{I}: 3$ aceticalcohol or in 45 per cent. acetic acid and the material was then examined by the use of Feulgen squashes.

The rodents Rattus norvegicus and Microtus agrestis were reared in the laboratory and the animals were killed before the uterus was removed. Chromosome examinations were then also made by the use of Feulgen squashes (Sachs, 1952b, 1953b).

The chromosome picture which is obtained in a particular tissue depends not only on the mitotic activity and on the methods of fixation, staining and dehydration. It also depends upon the type of cell. Thus although the cornea of the eye and the epidermis of the ear in mammals show periods of high mitotic activity, these tissues are not the most suitable for accurate chromosome counts. The cells of the endometrium can give better chromosome pictures than either of these tissues, but even the endometrium does not give such good chromosome figures as those obtained from some spermatogonial cells. Counts of the exact number of chromosomes is therefore not always possible in the cells of the endometrium.

The chromosome counts in the present study have been made with an accuracy of about 5 per cent. of the chromosomes or even better. The application of more pressure in making the squashes might have produced an even higher degree of accuracy but this would have resulted in an excessive breaking of the cells which it is best to avoid. In the scoring of chromosome numbers I have taken great care that no damaged cells were included.

\section{HOMO SAPIENS}

A characteristic feature of the œstrus cycle in man and other primates is the existence of a period of uterine bleeding known as menstruation. Each cycle includes a period of growth and a period 
of regression of the endometrium, and this is followed by bleeding and endometrial destruction during menstruation. After menstruation the endometrium is repaired during the growth period and the whole cycle is again repeated. The human cycle takes about 28 days and good mitotic activity in the endometrium is found during the growth period at about 7-1 2 days after the beginning of the cycle (Timonen, 1950). The biopsy material used in the present study was therefore taken at the growth stage of the human cycle.

The endometrial biopsies at this stage of the normal cycle were obtained from 2 women in England and from I woman in Israel. Chromosome counts were made on 50 cells and these have shown no variations from the normal $(2 n=48)$ diploid chromosome number. It was also seen from the many dividing cells which were not so accurately counted that there is no extensive subdiploid variation in this somatic human tissue.

\section{RATTUS NORVEGICUS AND MICROTUS AGRESTIS}

The œestrus cycle in rodents is shorter than the cycle in man and there is no period of menstruation. The duration of the ostrus cycle in Microtus agrestis (the short-tailed bank vole) is not so exactly known. But Rattus norvegicus (the laboratory albino rat) has been extensively used for studies on the physiology of reproduction and it is known that the ostrus cycle takes about $4 \frac{1}{2}$ days. In both species periods of mitotic activity have been found during the normal development of the endometrium.

The chromosome numbers in the testes are $2 n=42$ for $R$. norvegicus and $2 n=50$ for $M$. agrestis. The species $M$. agrestis is especially favourable for somatic chromosome studies since its two sex chromosomes are considerably larger than any of the autosomes and they can be readily identified during the stages of mitosis (Sachs, 1953a). Chromosome counts have been made on 50 endometrial cells in each of the two species and these have shown no variations from the normal diploid chromosome number.* It could also be seen from the many dividing cells which were not so accurately counted that there is no extensive subdiploid variation.

\section{SUBDIPLOID VARIATION IN SOMATIC TISSUES}

The present study on the chromosomes of the normal human endometrium, which is substantiated by the study on the two rodents, is thus in contradiction to the previous report on the human endometrium (Timonen, 1950). In both the present and Timonen's observations the biopsy material was taken at the same stage of the human cycle and the cytological study was based on the use of Feulgen squashes. There is no doubt that Feulgen squashes can give satisfactory

* The same situation was found in a count of 20 cells of the cornea of the albino rat. 
results for mammalian chromosomes, but in the making of squash preparations one has to be very careful that the cells have not been damaged by the squashing (Sachs, I953c). Excessive pressure will break the cells and this is especially true of prophase at which many of Timonen's counts were made. The many subdiploid and subhaploid chromosome numbers which have been reported in the human endometrium may have been due to the counting of broken cells. Another possibility is that previous observations have not been based on normal human material. The reported extensive subdiploid and subhaploid variation in other normal mammalian tissues (Therman and Timonen, 195 I) should also be examined in the light of the chromosome condition in the normal endometrium.

There are some examples of normal mitoses in chromosome deficient pollen grains (Darlington and Mather, I949). A certain amount of subdiploid variation has also been found in some plants (Sachs, I 952a), amphibians (Fankhauser, I 945), fish embryos (Svardson, I945), and mouse embryos (Beatty and Fischberg, I95 I). But in these cases the cells with subdiploid chromosome numbers have been produced by environmental or by gene controlled mitotic abnormalities which are not characteristic of normal tissues. Subdiploid and subhaploid chromosome numbers have been reported in a " polyploid" rabbit (Melander, I950) and a "polyploid" pig (Häggquist and Bane, I $95 \mathrm{I}$ ), but no such variation was found in polyploid implanted mouse embryos (Fischberg and Beatty, I95I).

Even in mammalian tumours, some of which show considerable variations in chromosome numbers (Koller, 1947), the existence of large numbers of subhaploid cells as a characteristic of malignant tumours is open to question. This is shown by studies on ascites tumours. These studies should be particularly accurate since ascites tumours are probably the easiest mammalian material for chromosome studies. These tumours consist of a suspension of free cells which are easily squashed and there is almost no chance of any appreciable errors in the counting of chromosomes. It is thus significant that studies on ascites tumours of rat (Makino, I952) and of mouse (Levan and Hauschka, r952) have not shown a single cell with a subhaploid chromosome number.

There is also some evidence on somatic chromosomes from cultures of mammalian tissues. But the conditions of a tissue in culture are very different from those existing inside the body and only slight variations in, e.g. the salt concentration of the medium, can alter the behaviour of the chromosomes and spindle. There is no doubt that good chromosomes figures can be obtained from mammalian tissue cultures (Hsu, I952). But until the same tissues have been examined as they exist inside the animal one can never be certain how far any observed abnormalities are due to the conditions of the culture. Even with this possible drawback of the results from tissue cultures, chromosome counts on cultures of embryonic tissues of mouse, guinea-pig, 
dog, and man, have all shown frequency peaks at the normal diploid chromosome number (Hsu, I953).

It is not impossible that reduction, or increase, in chromosome number as a result of such mechanisms as chromosome lagging, nondisjunction, or an occasional multipolar spindle may normally occur in some somatic cells. But there is no evidence of anything like a higher frequency of subdiploid than of diploid cells, as the usual condition of normal somatic tissues.

\section{POLYPLOID VARIATION IN SOMATIC TISSUES}

The absence of extensive subdiploid variation in normal somatic tissues does not, however, mean that all somatic cells have the same chromosome number. In addition to an occasional polyploid cell in many tissues, and possibly some small percentage of subdiploid or hyperdiploid cells, a high frequency of polyploid cells has been found in the blood (La Gour, I944) and liver (Biesele, 1944) of normal mammals, and in a variety of tissues in some other normal animals and plants (Huskins, 1947). Huskins assumes that genes must reproduce in order to survive and that the polyploidy is due to chromosome reproduction, which is essential for gene survival, in functional cells without adequate nuclear division.

There is, however, another explanation. It is of course clear that polyploidy as such is not necessarily a sign of degeneration and this can be seen from the existence of polyploid evolution. This is an adaptive form of polyploidy. But the high degrees of polyploidy in differentiated tissues, i.e. in the tissues which are not going to reproduce the organism, may merely be a sign that the cells are degenerating. This is then a pathological form of polyploidy. These cells may have become polyploid because they have lost some of their capacity for normal reproduction such as the ability to form functional spindles. In addition to such a loss as the ability to form spindles, further degeneration may result in a loss of the capacity for normal chromosome reproduction, thus leading to chromosome breakage. This condition has in fact been found in differentiated tissues of plants (Levan, I95 I) which show many chromosome breaks in the highly polyploid cells. Similar chromosome degeneration may also occur in non-polyploid cells.

The same degeneration phenomena can be found in cancer tissues. It has often been assumed that chromosome abnormalities and great variations in chromosome number are a constant characteristic of cancers (Hauschka, I952). But not all cancers have the same cytological picture, and during an investigation on a range of mouse tumours I have found some cancers which show no chromosome or spindle abnormalities. The behaviour of the different types of cancer can best be explained by the existence of basic tumour cells (Makino, I952), these being the cells which keep the tumour going and which maintain the distinct pattern of each tumous. In the cancers with no abnormalities the basic tumour cells, and all the other cells of the 
tumour, would have the diploid number of chromosomes. In other cancers the existence of these basic tumour cells with either the diploid, or in some types of cancer with the tetraploid chromosome number, can be inferred from studies on ascites tumours (Levan and Hauschka, 1952). The more than diploid cells in cancers with diploid basic tumour cells, and the more than tetraploid cells in cancers with tetraploid basic tumour cells, in addition to any cells with aneuploid numbers or chromosomes and spindle abnormalities in these cancers are thus merely the by-products of the basic tumour cells. The abnormalities observed in these cells are then the result of a loss of some of the normal reproductive capacity. In some cases basic tumour cells may have less than the full chromosome complement, so that some cancers may have near diploid or near tetraploid basic tumour cells (Makino, r952; Hauschka and Levan, r953).

This concept of basic tumour cells is also of importance in cancer chemotherapy. Decisions on the activity of chemical compounds on the basis of chromosome abnormalities produced in a particular tumour may merely be the judgment of compounds which kill already dying cells and leave the basic tumour cells untouched. The production of chromosome breaks in other organisms, such as the root tips of plants, whilst of great importance for an understanding of chromosome structure and behaviour, is therefore also of limited value in relation to tumour problems in mammals. In addition the absorption, utilisation, and effects of chemical substances in plants may be very different to the position which is found in mammals. This can be seen in the case of penicillin which is considered to be an effective mutagenic agent on the chromosomes of Allium root tips (Levan, I95I). Penicillin is, however, commonly used in man and the appropriate doses have shown no such drastic changes in human cells.

High frequencies of polyploidy and chromosome abnormalities can thus be found in some somatic tissues. But the existence of this chromosome duplication and of abnormalities may merely be an indication that the cells are no longer able to divide normally and that they have lost some of their reproductive capacity.

\section{SUMMARY}

The endometrium of the mammalian uterus is a favourable material for chromosome studies on normal somatic tissues. Uterine changes during the ostrus cycle are correlated with periods of mitotic activity in the endometrium so that mitoses can be examined even in adult animals. A study of the normal endometrium in Homo sapiens (the human female), Rattus norvegicus (the albino rat), and Microtus agrestis (the short-tailed bank vole), has shown no evidence of extensive subdiploid variation within this somatic tissue. There is also no indisputable evidence of extensive subdiploid variation as the usual constituent of other normal somatic tissues. Although some somatic 
tissues contain high frequencies of polyploid cells, these cells and any with chromosome or spindle abnormalities may merely be degenerating cells which have lost some of their normal reproductive capacity.

\section{REFERENCES}

ANDRES, A. H., AND Jiv, B. v. 1936. Somatic chromosome complex of the human embryo. Cytologia, 7, 371-388.

BEATTY, R. A., AND FISCHBERG, M. I95I. Heteroploidy in mammals. I. Spontaneous heteroploidy in pre-implantation mouse eggs. F. Gént., 5o, 345-359.

BIESELE, J. J. I944. Chromosome complexity in regenerating rat liver. Cancer Research, 4, 232-235.

DARlington, C. D., AND mather, K. I949. The Elements of Genetics. London : Allen and Unwin.

FANKHAUSER, G. 1945. The effects of changes in chromosome number on amphibian development. Quart. Rev. Biol., 20, 20-78.

FISCHBERG, M., AND BEATTY, R. A. I95I. Spontaneous heteroploidy in mouse embryos up to mid-term. F. Exper. Zool., I18, $321-332$.

HAGGQUIST, G., AND BANE, A. I95I. Colchininduzierte Heteroploidie beim Schwein. Kgl. Sv. Vetenskapsakad Handl., Ser. 4, Bd. 3, No. 2, I-I4.

HAUSCHKA, T. S. I952. Immunologic aspects of cancer. Cancer Research, I2, 6 I5-633.

HAUSCHKA, T. S., AND LEVAN, A. I953. Inverse relationship between chromosome ploidy and host-specificity of sixteen transplantable tumors. Exp. Cell Res., $4,457-467$.

HsU, T. C. 1952. Mammalian chromosomes in vitro. I. The karyotype of man. 7. Hered., 43, I67-I 72 .

HsU, T. C. I953. Variation of chromosome number in tissue culture. Anat. Rec., 115, 325.

HUSKINS, C. L. I947. The subdivision of the chromosomes and their multiplication in non-dividing tissues : possible interpretations in terms of gene structure and gene action. Amer. Nat., $81,40 \mathrm{I}-434$.

KARPLUS, H. I930. Ein Beitrag zur Kenntnis der somatischen Mitose beim Menschen. Ztschr. f. Zellforsch., 10, 30-52.

KEMP, T. I 930 . Uber die somatischen Mitosen bei Menschen und warm-blutigen Tieren under normalen und pathologischen Verhältnissen. Ztschr.f. Zellforsch., II, 429-444.

KolleR, P. G. 1947. Abnormal mitosis in tumours. Brit. F. Cancer, 1, 38-46.

LA COUR, L. F. I 944 . Mitosis and cell differentiation in the blood. P.R.S. Edin., B., $62,73-85$.

LEVAN, A. 195I. Chemically induced chromosome reactions in Allium cepa and Vicia faba. Cold Spring Harbor Symp. Quant. Biol., 16, 233-242.

LEVAN, A., AND HAlschKa, T. S. I952. Chromosome numbers of three mouse ascites tumours. Hereditas, $38,25 \mathrm{I}-255$.

MAKINo, s. 1952. A cytological study of the Yoshida sarcoma, an ascites tumor of white rats. Chromosoma, $4,649-674$.

MELANDER, y. 1950. Chromosome behaviour of a triploid adult rabbit. Hereditas, $36,335-34$ I.

SACHS, LEO. I952a. Chromosome mosaics in experimental amphiploids in the Triticine. Heredity, 6, I 57-I 70.

SACHS, LEO. 1952b. Polyploid evolution and mammalian chromosomes. Heredity, $6,357-364$.

SACHS, LEO. I953a. The giant sex chromosomes in the mammal Microtus agrestis. Heredity, 7, 227-238.

SACHS, LEO. I953b. Simple methods for mammalian chromosomes. Stain Techn., 28, $169-172$. 
SACHS, LEO. I953C. Subdiploid chromosome variation in man and other mammals. Nature, I72, 205-206.

svärdson, G. 1945. Chromosome studies on Salmonida. Medd. St. undersökn. f. Söttvattenfisket., No. 23, I-I 5 I.

THERMAN, E., AND TIMONEN, S. I95I. Inconstancy of the human somatic chromosome complement. Hereditas, 37, 266-279.

TIMONEN, S. 1950. Mitosis in normal endometrium and genital cancer. Acta Obstetr. Gynecol. Scand., 3I, Suppl. 2, I-88.

TIMONEN, S., AND THERMAN, E. I950. Variation of the somatic chromosome number in man. Nature, $166,995-996$. 